\title{
KADAR LIKOPEN EKSTRAK KASAR BUAH TOMAT DALAM VCO (VIRGIN COCONUT OIL) PADA PERENDAMAN SUHU RUANG
}

\section{[Yield of Tomatoes Crude Extract Lycopene in VCO (Virgin Coconut Oil) on Immersion at Room Temperature]}

\author{
Enni Indriani ${ }^{{ }^{\star}}$, Ruslan ${ }^{1}$, Prismawiryanti $^{1}$, Pasjan Satrimafitrah ${ }^{1}$ \\ 1) Jurusan Kimia, Fakultas MIPA, Universitas Tadulako \\ Jl. Soekarno Hatta, Kampus Bumi Tadulako Tondo Palu, Telp. 0451- 422611 \\ *)Corresponding Author: enni.indriani01@gmail.com, hp.081253103987
}

Diterima 17 April 2018, Disetujui 30 Juli 2018

\begin{abstract}
Lycopene is one of the carotenoid compounds that can act as antioxidant which is soluble in oil due to its lipophilic character. This research produced lycopene from tomatoes crude extract in which facilitated by VCO. The objective of this research isto find out the best ratio tomatoes crude extract and VCO in extracting lycopene, and also the extraction time to produce the high concentration of lycopene from VCO at room temperature. The ratio of tomatoes crude extract and VCO was done at $1: 40,2: 40,3: 40,4: 40,5: 40(\mathrm{w} / \mathrm{v})$. The extraction time was done up to 7 weeks. The results showed that the best ratio of to produce lycopene was at 5:40, and the best time of extraction was in the first week which reached the high concentration of lycopene at $0.283 \mathrm{~g}$.
\end{abstract}

Keywords: Tomato extract, lycopene, VCO, immersion time

\begin{abstract}
ABSTRAK
Likopen merupakan salah satu senyawa karotenoid yang dapat berperan sebagai antioksidan yang memiliki sifat larut dalam minyak karena bersifat lipofilik. Penelitian ini memproduksi likopen yang berasal dari ekstrak kasat buah tomat dengan merendamnya dalam VCO. Tujuan penelitian ini untuk mengetahui rasio terbaik dariekstrak kasar buah tomat terhadap VCO dalam menghasilkan likopen, dan juga waktu ekstraksi untuk menghasilkan konsentrasi likopen tertinggi dari ekstraksi atau perendaman ekstrak kasar buah tomat dalam VCO pada suhu ruang. Rasio antara ekstrak kasar buah tomat dan VCO adalah 1:40, 2:40, 3:40, 4:40, 5:40 (b/v) dengan masa ekstraksi mencapai 7 minggu. Hasil penelitian menunjukkan rasio ekstrak likopen kasar buah tomat terbaik pada penelitian ini yaitu 5:40 dan waktu ekstraksi terbaik adalah pada minggu pertama, dengan kadar likopen tertinggi sebesar 0,283 g.
\end{abstract}

Kata kunci: Ekstrak tomat, likopen, VCO, waktu perendaman 


\section{LATAR BELAKANG}

Tomat (Lycopersicum esculentum Mill) termasuk salah satu komoditii hortikultura dan sumber penghasil karotenoid potensial yang memiliki nilai ekonomi tinggi dalam pasar industri Mappiratu et al., (2010). Tomat memiliki kandungan senyawa polifenol dan vitamin C yang berperan sebagai antioksidan serta kandungan karotenoid yang dominan yakni pigmen likopen Watson, (2003). Kemampuan likopen untuk mengontrol radikal bebas 100 kali lebih efisien dibanding vitamin $E$ (Maulida dan Zulkarnaen, 2010). Pada bidang kesehatan, likopen berfungsi untuk mencegah penyakit kardiovaskular, kencing manis, osteoporosis, infertilitas, kanker prostat dan kerusakan pangan yang disebabkan oleh oksidasi (Montesano et al., 2006).

Produksi likopen ditunjang oleh larutan pengekstrak, Preedy dan Ronald (2008) melaporkan bahwa kelarutan likopen di dalam minyak sekitar $0,2 \mathrm{mg} / \mathrm{mL}$ pada temperatur ruang. Mortensen et al. (2001) menyatakan bahwa likopen bersifat lipofilik atau larut dalam minyak, sehingga penambahan minyak sayur atau minyak zaitun dalam makanan yang mengandung tomat dapat meningkatkan penyerapan likopen. Mu'nisa (2012), Eveline et al. (2014), dan Suryati (2011) telah menggunakan likopen sebagai antioksidan untuk meningkatkan stabilitas minyak.

Pada penelitian ini dilakukan dengan menggunakan minyak VCO sebagai pengekstrak likopen dari ekstrak kasar buah tomat untuk menghasilkan likopen dengan kadar tertinggi. Perlakuan ekstraksi adalah dengan perbandingan rasio antara ekstrak kasar buah tomat dan minyak VCO, dan waktu ekstraksi (perendaman).

\section{METODE PENELITIAN}

\section{Bahan dan Peralatan}

Bahan yang digunakan dalam penelitian ini adalah buah tomat (lycopersicum pyriforme) yang diperoleh dari pasar inpres Kota Palu, bahan lainnya yang digunakan sebagai pengekstrak yaitu minyak VCO (Virgin Coconut Oil).

Adapun alat yang digunakan dalam penelitian ini mencakup spektrofotometer UV-Vis, neraca analitik, kuvet, aluminuim foil, ayakan 60 mesh, kain saring, termometer, panci, kompor, baskom, blender, talang aluminium, alat pengering surya, pisau dan alat-alat gelas yang umum digunakan dalam Laboratorium kimia.

\section{Prosedur Penelitian}

\section{Produksi Likopen Ekstrak Kasar Buah Tomat}

Buah tomat yang sudah bersih ditimbang, ditambahkan air dengan rasio air terhadap buah tomat (rasio air/buah tomat) 1:1 atas dasar volume berat $(\mathrm{v} / \mathrm{b})$. Buah tomat dihancurkan dengan blender, kemudian pasta tomat yang diperoleh dipanaskan pada suhu $70^{\circ} \mathrm{C}$ selama 30 menit, selanjutnya disaring ampas atau residu yang dihasilkan dari hasil 
penyaringan dikeringkan dengan alat pengering surya. Residu kering yang merupakan likopen ekstrak kasar buah tomat dihancurkan dengan blender. Selanjutnya diayak menggunakan ayakan 60 mesh.

\section{Ekstraksi Likopen Ekstrak kasar Buah Tomat Dengan Minyak VCO}

Ekstraksi likopen dengan minyak VCO dilakukan menggunakan metode maserasi. Ekstraksi likopen kasar buah tomat yang telah dihaluskan dimasukkan ke dalam botol vial dan dicampurkan dengan VCO dengan perbandingan 1:40, $2: 40, \quad 3: 40, \quad 4: 40$, dan 5:40 (b/v). Selanjutnya campuran dikocok selama 10 menit dan diamkan selama 7 minggu dengan waktu pengamatan masingmasing minggu 1 , minggu 2 , minggu 3 , minggu 4, minggu 5, minggu 6 dan minggu 7. Setiap minggunya dilakukan penentuan kadar likopen dalam minyak dengan mengukur absorbansinya pada panjang gelombang maksimum (480 nm) menggunakan alat Spektrofotometer UVVis.

\section{Penentuan kadar likopen dalam VCO}

Kadar likopen dalam VCO
ditentukan dengan mengukur
absorbansinya menggunakan rumus
Hukum Lambert-Beer.

$$
\mathrm{C}=\frac{A \times V \times f p}{E_{1 c m}^{10} X b}
$$

Ket:

$\mathrm{C}=$ Konsentrasi $\mathrm{g} / 40 \mathrm{~mL}$ dalam VCO

A $=$ Absorban

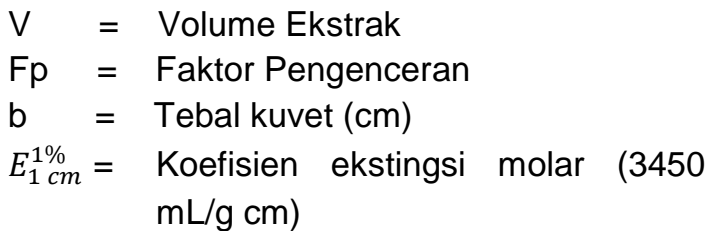

\section{HASIL DAN PEMBAHASAN}

\section{Ekstrak Kasar Likopen Buah Tomat}

Likopen kasar buah tomat yang diperoleh dari penelitian ini yaitu berbentuk serbuk berwarna merah jingga, seperti terlihat pada Gambar 1.

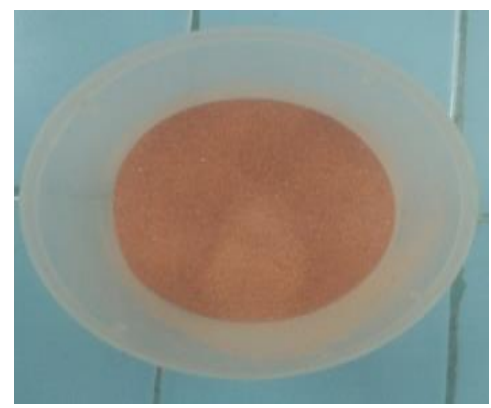

Gambar 1. Likopen Ekstrak Kasar Buah Tomat

Pada penelitian ini dilakukan ekstraksi likopen kasar dari buah tomat menggunakan pelarut air dengan rendemen yang dihasilkankan sebesar $2,46 \%$. Hasil yang diperoleh relatif sama dengan yang diperoleh oleh Mappiratu et al., (2010), yakni 2,5\%, sedangkan Ibrahim (2011) memperoleh rendemen likopen kasar sebesar 2,43\%. Rendemen likopen kasar selain dipengaruhi oleh rasio air/tomat, suhu dan waktu perebusan, juga dipengaruhi oleh jenis buah tomat dan tingkat kematangan (Mappiratu et al., 2010).

Pengaruh rasio ekstrak kasar likopen terhadap VCO dan waktu perendaman

Berdasarkan hasil penelitian ini diperoleh grafik hubungan rasio ekstrak 
likopen kasar : VCO dan waktu perendaman terhadap konsentrasi likopen disajikan pada Gambar 2.

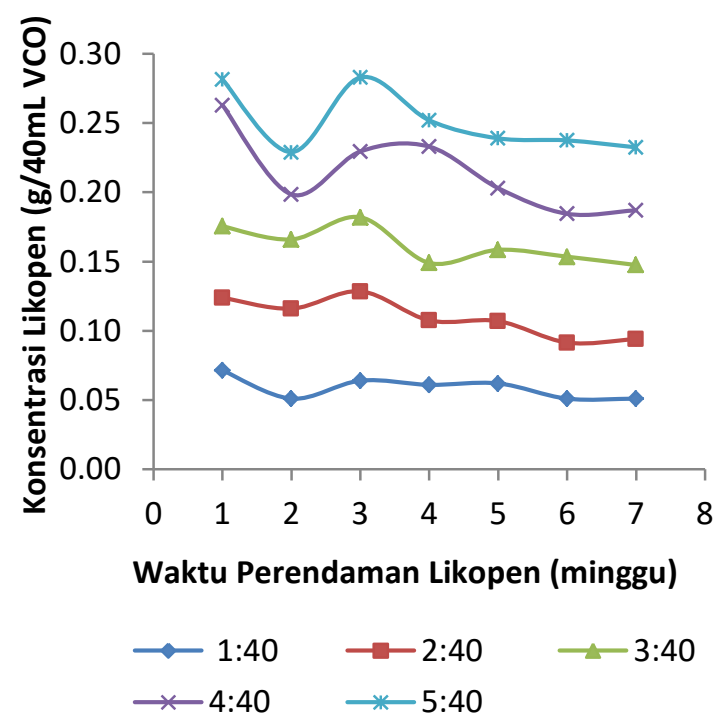

Gambar 2. Pengaruh rasio ekstrak likopen kasar dan waktu perendaman terhadap konsentrasi likopen dalam VCO (Virgin Coconut Oil).

Gambar 2 menunjukkan bahwa konsentrasi likopen pada tomat akan meningkat seiring bertambahnya rasio ekstrak kasar likopen terhadap VCO. Rasio yang mengasilkan likopen tertinggi yakni rasio 5:40 (b/v). Berdasarkan uji statistik diperoleh bawa perlakuan variasi rasio berpengaruh nyata terhadap konsentrasi likopen yang terekstrak. Menurut Mappiratu et al. (2010) kelarutan komponen tomat meningkat dengan meningkatnya penggunaan pelarut.

Konsentrasi likopen dalam minyak VCO pada minggu ke-1 yang tertinggi diperoleh 0,283 g/40mL VCO pada rasio 5:40. Selanjutnya konsentrasi likopen dalam VCO mengalami penurunan pada minggu ke-2, hal ini diduga karena likopen mengalami kerusakan karena terjadinya proses oksidasi. Menurut Britton et al., (1995), senyawa karotenoid mudah teroksidasi karena banyak memiliki ikatan rangkap terkonjugasi sehingga mengakibatkan terjadinya pemucatan pada pigmen warna, kemudian peningkatan kadar likopen pada minggu ketiga pada semua rasio yang digunakan diduga karena masih terjadi ekstraksi likopen oleh VCO, selanjutnya terjadi penurunan kadar likopen dalam VCO dari minggu ke-3 hingga minggu ke-7. Hal ini disebabkan adanya kerusakan pada likopen, yang ditandaidari memudarnya intensitas warna ekstrak likopen dalam VCO yang dihasilkan.

Uji statistik menunjukkan bahwa waktu perendaman berpengaruh terhadap konsentrasi likopen yang terdapat dalam VCO. Hasil penelitian ini menunjukkan bahwa selama 7 minggu perendaman kadar likopen mengalami penurunan tertinggi sebesar 29,17\% untuk rasio 1:40. Hal ini sejalan dengan hasil penelitian Montesano et al. (2006) yang memperoleh penurunan kadar likopen murni dalam minyak zaitun sebesar $38,09 \%$ selama 37 minggu penyimpanan.

Kadar likopen terhadap waktu penyimpanan akan mengalami penurunan seiring dengan semakin lamanya waktu penyimpanan (Safitri, 2013) Hal ini disebabkan oleh oksidasi cahaya, oksigen dan logam (Allen et al., 2003 dalam Sari, 2011). Pemaparan cahaya dapat menurunkan stabilitas likopen yang dipengaruhi oleh suhu penyimpanan 
(Amila et al., 2010), sehingga akan mengakibatkan menurunnya mutu produk likopen (Safitri, 2013).

Menurut Febriansyah et al. (2008), likopen mengalami degradasi akibat proses isomerisasi dan oksidasi dengan oksigen, cahaya, teknik pengeringan, suhu tinggi, penyimpanan, proses pengelupasan dan asam. Adanya ikatan ganda terkonjugasi, menyebabkan karetenoid peka terhadap oksidasi terutama dalam bentuk padat, oksidasi karotenoid akan lebih cepat dengan adanya sinar dan katalis logam, khususnya tembaga, besi, baja, dan mangan (Walfford, 1980 dalam Mappiratu 1990).

\section{KESIMPULAN}

Rasio ekstrak kasar likopen terhadapa VCO 5:40 (b/v) menghasilkan kadar likopen tertinggi, yaitu 0,283 g/40mL VCO pda minggu pertama. Kadar likopen menurun pada penyimpanan hingga 7 minggu dengan penurunan tertinggi terjadi pada rasio likpen terhadap VCO 1:40, yaitu $29,17 \%$.

\section{DAFTAR PUSTAKA}

Amila, Hadiansyah, C., Fazriah, Y., Darusman, F. dan Topik, I. 2010. Pengaruh Jenis Penyalut Terhadap Stabilitas Likopen Dalam Bentuk Sediaan Mikrokapsul. IJPST. 3(3).

Britton G, S.L. Jensen, dan H. Pfander. 1995. Carotenoids Volume 1A: Isolation and Analysis. Berlin: Birkhauser Verlag.
Eveline, Tagor M. S., dan Sanny. 2014. Studi Aktivitas Antioksidan Pada Tomat (Lycopersicon esculentum) Konvensional dan Organik Selama Penyimpanan. Prosiding SNST Fakultas Teknik. 1(1).

Febriansyah, R., L. Indriyani., K.D Palupi dan M. Ikawati. 2008. Tomat (Solanum Lycopersium L.) Sebagai Agen Kemopreventif Potensial. Diunduh di https://www.researchgate.net/public ation/237534133_TOMAT_Solanum _lycopersicum_L_SEBAGAI_AGEN _KEMOPREVENTIF_POTENSIAL, pada tanggal 3 Januari 2018.

Ibrahim, N. 2011. Kajian Waktu Simpan Likopen Dari tomat (Lycopersicum pyriforme) dalam Kemasan kapsul. [Tesis]. Palu: Program Pascasarjana Universitas tadulako,

Mappiratu. 1990. Produksi Beta-karoten pada Limbah Cair Tapioka dengan Kapang Oncom Merah. [Tesis]. Bogor: Sekolah Pascasarjana. IPB.

Mappiratu, Nurhaeni dan Ila Israwaty. 2010. Pemanfaatan tomat afkiran untuk produksi likopen. Media Litbang Sulteng, 3(1), 64-69.

Maulida, D., dan Zulkarnaen, N. 2010. Ekstraksi antioksidan (likopen) dari buah tomat dengan menggunakan solven campuran $\mathrm{n}$-heksan, aseton dan etanol. [Skripsi]. Jurusan Teknik Kimia, Fakultas Teknik, Universitas Diponegoro. Semarang.

Mu'Nisa. 2012. Analisis Kadar Likopen dan Uji Aktivitas Antioksidan Pada Tomat Asal Sulawesi Selatan. [Skripsi]. Makassar: Jurusan Biologi, FMIPA, Universitas Negeri Makassar

Mortensen, A., L, H. Skibsted, dan T. G. Truscott. 2001. The interaction of dietary carotenoids with radikal 
species. Archives of Biochemistry and Biophysics. 385(1): 13-19.

Montesano, D., L. Cossignani., G. D'Arco., M. S. Simonetti, dan P. Damiani. 2006. Pure lycopene from tomato preserves extra virgin olive oil from natural oxidative events during strorage. JAOCS, 83 (11) : 933 941.

Preedy, V. R., dan Ronald, R. W., (2008). Lycopene: nutritional, medicinal and therapeutic properties. Enfield: Science Publisher.

Safitri, N. 2013. Kajian Aktivitas Antioksidan Ekstrak Likopen dari Buah Tomat (Lycopersicum pyriforme) Selama Penyimpanan Pada Suhu Ruang. [Skripsi]. Palu: Program Studi Kimia, Fakultas Matematika dan IImu Pengetahuan Alam. Universitas Tadulako.

Sari, M.A. 2011. Penerapan Model Kinetika Reaksi untuk Menduga Umur Simpan Likopen dari Buah Semangka (Citrullus vulgaris Schard) dalam Kemanasan Kapsul. Prosiding Seminar Nasional. "Pemberdayaan Potensi Daerah Melalui Pengembangan Pendidikan, Sains, dan Teknologi". Palu 23 Juli 2011.

Suryati, 2011. Penambahan Karoten Untuk Meningkatkan Stabilitas dan Daya Anti Bakteri Virgin Coconut Oil (VCO). Surabaya: Airlangga University Library.

Watson, R. R. , 2003. Functional Foods and Nutraceuticals in Cancer Prevention. lowa: Wiley-Blackwell. 